\title{
Amelioration of Smoke Taint in Cabernet Sauvignon Wine via Post-Harvest Ozonation of Grapes
}

\author{
Margherita Modesti ${ }^{1,2, *}$, Colleen Szeto ${ }^{2,3}{ }^{\oplus}$, Renata Ristic $2,3\left(\mathbb{D}\right.$, WenWen Jiang ${ }^{4}$, Julie Culbert ${ }^{4}$, Cesare Catelli ${ }^{5}$, \\ Fabio Mencarelli ${ }^{6}$, Pietro Tonutti ${ }^{1}$ and Kerry Wilkinson ${ }^{2,3, *(D)}$ \\ 1 Life Sciences Institute, Scuola Superiore Sant'Anna, Piazza Martiri della Libertà 33, 5612 Pisa, Italy; \\ pietro.tonutti@santannapisa.it \\ 2 Department of Wine Science, Waite Research Institute, The University of Adelaide, PMB 1, \\ Glen Osmond, SA 5064, Australia; colleen.szeto@adelaide.edu.au (C.S.); renata.ristic@adelaide.edu.au (R.R.) \\ 3 The Australian Research Council Training Centre for Innovative Wine Production, PMB 1, \\ Glen Osmond, SA 5064, Australia \\ 4 The Australian Wine Research Institute, P.O. Box 197, Glen Osmond, SA 5064, Australia; \\ maddy.jiang@awri.com.au (W.J.); julie.culbert@awri.com.au (J.C.) \\ 5 P.C. di Pompeo Catelli S.R.L., Via Roma 81, Uggiate Trevano, 22029 Como, Italy; cesare.catelli@pinco-sa.com \\ 6 Department of Agriculture Food and Environment, University of Pisa, Via del Borghetto 80, 56124 Pisa, Italy; \\ fabio.mencarelli@unipi.it \\ * Correspondence: margherita.modesti@santannapisa.it (M.M.); kerry.wilkinson@adelaide.edu.au (K.W.)
}

\section{check for} updates

Citation: Modesti, M.; Szeto, C.; Ristic, R.; Jiang, W.; Culbert, J.; Catelli, C.; Mencarelli, F.; Tonutti, P.; Wilkinson, K. Amelioration of Smoke Taint in Cabernet Sauvignon Wine via Post-Harvest Ozonation of Grapes. Beverages 2021, 7, 44. https:// doi.org/10.3390/beverages7030044

Academic Editors:

Stamatina Kallithraka and

Matteo Marangon

Received: 21 May 2021

Accepted: 25 June 2021

Published: 1 July 2021

Publisher's Note: MDPI stays neutral with regard to jurisdictional claims in published maps and institutional affiliations.

Copyright: (c) 2021 by the authors. Licensee MDPI, Basel, Switzerland. This article is an open access article distributed under the terms and conditions of the Creative Commons Attribution (CC BY) license (https:// creativecommons.org/licenses/by/ $4.0 /)$.
Abstract: Strategies that mitigate the negative effects of vineyard exposure to smoke on wine composition and sensory properties are needed to address the recurring incidence of bushfires in or near wine regions. Recent research demonstrated the potential for post-harvest ozonation of moderately smoke-exposed grapes to reduce both the concentration of smoke taint marker compounds (i.e., volatile phenols and their glycosides) and the perceived intensity of smoke taint in wine, depending on the dose and duration of ozone treatment. The current study further evaluated the efficacy of ozonation as a method for the amelioration of smoke taint in wine by comparing the chemical and sensory consequences of post-harvest ozonation (at $1 \mathrm{ppm}$ for $24 \mathrm{~h}$ ) of Cabernet Sauvignon grapes following grapevine exposure to dense smoke, i.e., ozone treatment of more heavily tainted grapes. Ozonation again yielded significant reductions in the concentration of free and glycosylated volatile phenols-up to $25 \%$ and $30 \%$, respectively. However, although the intensities of smoke-related sensory attributes were generally lower in wines made with smoke-exposed grapes that were ozonated (compared to wines made with smoke-exposed grapes that were not ozonated), the results were not statistically significant. This suggests that the efficacy of ozone treatment depends on the extent to which grapes have been tainted by smoke.

Keywords: Cabernet Sauvignon; descriptive analysis; glycoconjugates; guaiacol; mitigation; ozone; syringol; volatile phenols

\section{Introduction}

Globally, the occurrence of bushfires in or near prominent wine regions is increasing due to warmer and drier environmental conditions that are attributable to climate change [1-3]. This is particularly concerning for grape and wine producers because grapevine exposure to smoke can adversely affect grape and wine composition [4-9], in some instances leading to a perceptible taint characterized by smoky, medicinal, drying, and/or ashy characters $[4,8,10]$. The intensity of "smoke taint" in wine depends on the timing and duration of smoke exposure [11,12], as well as smoke density [13], i.e., factors that influence the extent to which smoke-derived volatile compounds can be adsorbed by grapes. These volatiles include phenols, such as guaiacol, $o^{-}, \mathrm{m}^{-}$, and $p$-cresol, and syringol, which are found in smoke as a consequence of the thermal degradation of lignin that occurs when plant material is burned [14]. Volatile phenols have also been found in 
smoke-affected grapes and wines made from smoke-affected grapes [4-13,15]. As such, they have become useful markers for the detection and/or quantification of smoke taint. However, several studies have demonstrated that following grapevine exposure to smoke, volatile phenols accumulate in leaves and fruit in glycosylated forms [13,16-20]. Glycosylation of volatile phenols by glucosyltransferase enzymes increases their solubility and stability, and likely occurs to mitigate any toxic effects or risk of cellular damage [21]. Volatile phenol glycosides are odorless, but during fermentation, they can be metabolized by yeast and enzymes to release volatile phenols $[4,7,8,20]$, which can then impart smoke-related sensory attributes in wine. A significant pool of volatile phenol glycosides typically remains in wines made from smoke-affected grapes $[7,8,13,18,20]$ and may also contribute to the sensory perception of smoke taint through in-mouth hydrolysis by salivary enzymes [22]. Analytical methods have therefore been developed to quantify volatile phenol glycosides $[17,18,20,23,24]$, so they can also be used as markers of smoke taint.

Researchers have quantified volatile phenols (in free and glycosylated forms) to evaluate the efficacy of methods that mitigate or ameliorate the impacts of grapevine smoke exposure. To date, there has been limited success with strategies that aim to reduce either the uptake of smoke in the vineyard $[13,19,25,26]$ or the extraction of smoke taint compounds from grapes during winemaking [27]. Thus, for now, the most effective remediation strategies involve removal of smoke volatiles from tainted wine using adsorbent materials, such as activated carbon, which can either be added directly to wine [28] or used in combination with nanofiltration [29]. However, recent research has shown that post-harvest ozone $\left(\mathrm{O}_{3}\right)$ treatment of smoke-exposed grapes can also reduce the concentration of volatile phenols (and their glycosides) in wine and the sensory perception of smoke taint [30,31].

Ozonation is often employed in food and beverage production as a sanitizing agent, but is known to stimulate biological responses, such as the biosynthesis of phenolic compounds, in different fruits and vegetables [32] and, specifically, in wine and table grapes $[33,34]$. In various crops, including grapes, the oxidation potential of $\mathrm{O}_{3}$ has been exploited to reduce the concentration of pesticide residues [35,36], to extend shelf life, [37], to control microbial growth $[38,39]$, or to enhance polyphenol and/or volatile concentrations [40-42], albeit the outcome of $\mathrm{O}_{3}$ treatment can depend on the duration of exposure, the dose rate, and the method of application. When moderately smoke-affected Merlot grapes were exposed to $3 \mathrm{ppm}$ of $\mathrm{O}_{3}$ for $12 \mathrm{~h}$ (post-harvest), no significant differences were observed in the volatile phenol or volatile phenol glycoside concentrations of the resulting wines [31]. However, a small but significant reduction in free and glycosylated volatile phenol concentrations was observed following post-harvest ozonation of grapes at $1 \mathrm{ppm}$ for $24 \mathrm{~h}$, and most importantly, the intensity of smoke-related wine sensory attributes was significantly diminished [31]. The current study aimed to further evaluate the efficacy of post-harvest ozonation as a method for amelioration of smoke taint in wine. It builds on previous research by comparing the chemical and sensory outcomes of $\mathrm{O}_{3}$ treatment of smoke-affected grapes from a different cultivar (i.e., Cabernet Sauvignon) and following exposure to dense smoke (i.e., more heavily tainted grapes).

\section{Materials and Methods}

\subsection{Smoke Exposure of Grapevines}

Cabernet Sauvignon grapevines (Vitis vinifera L.) grown in a vineyard on the University of Adelaide's Waite Campus (in Urrbrae, SA, Australia, $34^{\circ} 58^{\prime} \mathrm{S}, 138^{\circ} 38^{\prime} \mathrm{E}$ ) were exposed to smoke for $1 \mathrm{~h}$ (at $\sim 7$ days post-veraison) during the 2018/2019 growing season. Smoke treatments were applied to six adjacent vines (three vines at a time) using a purposebuilt smoke tent $(2.0 \mathrm{~m} \times 6.0 \mathrm{~m} \times 2.5 \mathrm{~m})$ and commercial smokers, which have been described previously [13,31]; barley straw $(\sim 5 \mathrm{~kg}$ in total) was burned throughout the treatment to maintain smoke production. Control (unsmoked) vines were separated from the smoke-exposed vines by at least one panel of buffer vines. The vineyard management was previously reported [13], but, briefly: vines were planted in 1998 in north-southaligned rows on their own roots and were trained to a bilateral cordon with a vertical 
shoot-positioned trellis system; they were hand-pruned (two nodes per spur) and drip irrigated (twice per week between fruit set and harvest).

\subsection{Post-Harvest Ozonation of Grapes}

Fruit ( $12 \mathrm{~kg}$ per treatment) was handpicked from the control and smoke-exposed grapevines when maturity sampling indicated that the total soluble solids (TSSs) were $21^{\circ}$ Brix (approximately four weeks after smoke exposure), as determined with an Atago digital refractometer (Tokyo, Japan). Control and smoke-exposed grapes were then randomly divided into six fruit parcels ( $2 \mathrm{~kg}$ each). Three parcels each of control and smoke-exposed fruit (arranged as a single layer of bunches) were treated with $1 \mathrm{ppm}$ of gaseous $\mathrm{O}_{3}$ (produced with an A series ozone generator, P.C. di Pompeo Catelli SRL, Uggiate-Trevano, Italy) for $24 \mathrm{~h}$ in a $4{ }^{\circ} \mathrm{C}$ cold room-hereafter, "control $+\mathrm{O}_{3}$ " and "smoke $+\mathrm{O}_{3}$ " treatments, respectively. The dose and duration of ozonation were determined according to conditions employed in previous studies involving ozonation of wine grapes $[30,34,40]$. The three remaining parcels of control and smoke-exposed fruit were also stored in the $4{ }^{\circ} \mathrm{C}$ cold room for $24 \mathrm{~h}$, but without ozonation-hereafter, "control" and "smoke" treatments, respectively. Following ozonation, fruit parcels were utilized in small-scale winemaking, with the three fruit replicates from each treatment becoming wine replicates.

\subsection{Small-Scale Winemaking}

Grape bunches ( $\sim 2 \mathrm{~kg}$ per replicate, per treatment) were destemmed and crushed by hand, after which $50 \mathrm{mg} / \mathrm{kg}$ of sulfur dioxide was added to the resulting must (as an $8 \%$ solution of potassium metabisulfite). The must $\mathrm{pH}$ was then adjusted to 3.5 with the addition of tartaric acid before addition of $100 \mathrm{mg} / \mathrm{L}$ of diammonium phosphate and inoculation with $150 \mathrm{mg} / \mathrm{L}$ of PDM yeast (Maurivin, AB Biotek, Sydney, NSW, Australia). Musts were fermented on skins at ambient temperature $\left(\sim 24^{\circ} \mathrm{C}\right)$ for seven days, during which time the cap was plunged twice per day. When the wines approached dryness (i.e., at $\sim 2 \mathrm{~g} / \mathrm{L}$ of residual sugar), they were pressed, and fermentation continued at ambient temperature $\left(\sim 24^{\circ} \mathrm{C}\right)$ until residual sugars were $<1 \mathrm{~g} / \mathrm{L}$ (determined enzymatically using a glucose/fructose test kit; Vintessential Laboratories Pty. Ltd., Dromana, VIC, Australia). Wines were then racked from gross lees and cold stabilized at $0{ }^{\circ} \mathrm{C}$ for 4 weeks before being bottled in $375 \mathrm{~mL}$ glass bottles with screw-cap closures. Prior to bottling, wine $\mathrm{pH}$ and free $\mathrm{SO}_{2}$ were adjusted to 3.5 and $20 \mathrm{mg} / \mathrm{L}$, respectively (again via addition of tartaric acid and potassium metabisulfite), and samples were collected for chemical analysis. Wines were cellared $\left(\right.$ at $\left.15{ }^{\circ} \mathrm{C}\right)$ for two months prior to sensory analysis.

\subsection{Chemical Analysis of Wine}

Chemical analyses were performed on wine replicates from each experimental treatment. Wine $\mathrm{pH}$ and titratable acidity (TA, expressed as $\mathrm{g} / \mathrm{L}$ of tartaric acid) were measured using a Mettler Toledo T50 autotitrator coupled to a Mettler Toledo InMotion Flex autosampler (Port Melbourne, VIC, Australia). Ethanol content (as \% alcohol by volume, abv) was measured with an alcolyzer (Anton Paar, Graz, Austria). Wine color density and hue were measured with an Infinite ${ }^{\circledR} 200$ PRO spectrophotometer (Tecan, Männedorf, Switzerland) using the modified Somers color assay [43].

The concentrations of volatile phenols (guaiacol, 4-methylguaiacol, $o-, m-$, and $p$-cresol, syringol, and 4-methylsyringol) were measured in wine by the Australian Wine Research Institute's Commercial Services laboratory, using gas chromatography-mass spectrometry and stable isotope dilution analysis (SIDA) methods reported previously [6,44]. The preparation of isotopically labeled standards $\left(d_{3}\right.$-guaiacol, $d_{3}-4$-methylguaiacol, $d_{7}-0$-cresol, and $d_{3}$-syringol), method validation, and instrument operating conditions are provided in these publications. The limit of quantitation for volatile phenols was 1-2 $\mu \mathrm{g} / \mathrm{L}$. The concentrations of volatile phenol glycosides were measured in wine (as syringol glucose-glucoside (gentiobioside) equivalents) using previously reported liquid chromatography-tandem mass spectrometry and SIDA methods [6,24]. Again, the preparation of the isotopically 
labeled standard ( $d_{3}$-syringol gentiobioside), method validation, and instrument operating conditions are provided in these publications. The limit of quantitation for volatile phenol glycosides was $1 \mu \mathrm{g} / \mathrm{L}$.

\subsection{Sensory Analysis of Wine}

Wine sensory profiles were determined by descriptive analysis (DA) [45] with a panel of 15 judges (10 female and 5 male, aged 25 to 53 years) comprising staff and students from the University of Adelaide and the Australian Wine Research Institute. Panelists were recruited based on their availability and prior involvement in DA of smoke-tainted wines; nine panelists had $>10$ years of experience in sensory analysis of smoke-tainted wines.

The panel evaluated 18 attributes generated in previous smoke taint studies, e.g., [8,46,47], comprising: fruit, smoke, cold ash, earthy, burnt rubber, and medicinal aromas; fruit, smoky, and medicinal flavors; ashy, woody, drying, and metallic aftertastes; bitterness, acidity, hotness, astringency, and body. Sensory assessments were performed in individual sensory booths under controlled environmental conditions (i.e., ventilation, lighting, and a constant temperature of $22-23^{\circ} \mathrm{C}$ ). Aliquots $(30 \mathrm{~mL}$ ) of the 12 wines were served in covered, 3-digit coded stemmed wine glasses, presented monadically using a randomized presentation order (across panelists). To minimize sensory fatigue, 1 min breaks were enforced between samples, with a 3 min break enforced after four samples. Distilled water and plain crackers were provided to panelists as palate cleansers. Panelists were asked to rate the intensity of sensory attributes using unstructured line scales, with "low" and "high" anchors placed at $10 \%$ and $90 \%$ of the scale, respectively. Data were acquired with the RedJade software (Redwood Shores, CA, USA).

\subsection{Statistical Analysis}

Chemical data were analyzed with one-way analysis of variance (ANOVA) using GenStat (19th Edition, VSN International Limited, Herts, UK). Mean comparisons were performed with the least significant difference (LSD) multiple comparison test at $p<0.05$. Sensory data were analyzed with two-way ANOVA, with the judges treated as a random effect and the samples as a fixed effect, by using SenPAQ (version 5.01, Qi Statistics, Reading, UK) and XLSTAT (version 2018.1.1, Addinsoft, New York, NY, USA). Again, mean comparisons were performed with the LSD multiple comparison test at $p<0.05$.

\section{Results and Discussion}

\subsection{Influence of Post-Harvest Ozonation on Wine Composition}

The compositional consequences of grapevine exposure to smoke and post-harvest ozonation of grapes were determined by comparing the volatile phenol and volatile phenol glycoside concentrations of finished wines (Table 1 and Table S1). Guaiacol and syringol were the only volatile phenols detected in the control wines (at 1 and $\sim 2 \mu \mathrm{g} / \mathrm{L}$, respectively), along with low levels of volatile phenol glycosides (i.e., $\leq 13.4 \mu \mathrm{g} / \mathrm{L}$ ); ozonation of the control grapes had no significant effect on the free or glycosylated volatile phenol concentrations of the control wines. In contrast, the concentrations of volatile phenols and their glycosides were elevated in wines made from smoke-exposed grapes, and ozonation of smoke-exposed grapes did significantly affect the concentrations of many of the smoke taint marker compounds measured (Table 1 and Table S1).

Guaiacol and $o$ - and $m$-cresols were the most abundant smoke-derived volatile phenols detected in free (aglycone) forms (at up to 30 and $8.3 \mu \mathrm{g} / \mathrm{L}$, respectively), while guaiacol and syringol were the most abundant glycosylated volatile phenols (at up to 340 and $614 \mu \mathrm{g} / \mathrm{L}$, respectively). The relative abundance of these compounds in wines made from smoke-exposed grapes was consistent with previous research $[8,13,31,48]$, but importantly, the concentrations detected confirmed that a high degree of smoke taint was achieved, as intended, i.e., the volatile phenol and/or volatile phenol glycoside concentrations were comparable to levels reported for wines made from grapes exposed to dense smoke [13] or wines deemed to be heavily smoke tainted by sensory analysis $[8,13]$. 
Table 1. Concentrations $(\mu \mathrm{g} / \mathrm{L})$ of volatile phenols and volatile phenol glycosides in Cabernet Sauvignon wines made with control or smoke-exposed grapes, with or without post-harvest ozone treatment (1 ppm for $24 \mathrm{~h})$.

\begin{tabular}{|c|c|c|c|c|c|}
\hline & Control & Control $+\mathrm{O}_{3}$ & Smoke & Smoke $+\mathrm{O}_{3}$ & $p$ \\
\hline guaiacol & $\operatorname{tr}$ & $1.0 \pm 1.0^{\mathrm{c}}$ & $30 \pm 4.5^{\mathrm{a}}$ & $23 \pm 1.5^{b}$ & $<0.001$ \\
\hline 4-methylguaiacol & nd & nd & $4.3 \pm 0.6^{\mathrm{a}}$ & $3.3 \pm 0.6^{b}$ & $<0.001$ \\
\hline$o$-cresol & nd & nd & $8.3 \pm 1.5$ & $7.0 \pm 0.01$ & ns \\
\hline$m$-cresol & nd & nd & $8.3 \pm 1.5$ & $7.0 \pm 0.01$ & ns \\
\hline$p$-cresol & nd & nd & $4.0 \pm 0.01$ & $4.0 \pm 0.01$ & ns \\
\hline syringol & $2.3 \pm 0.6^{\mathrm{c}}$ & $2.0 \pm 0.01^{\mathrm{c}}$ & $6.3 \pm 0.6^{\mathrm{a}}$ & $5.3 \pm 0.6^{b}$ & $<0.001$ \\
\hline 4-methylsyringol & nd & nd & nd & nd & - \\
\hline guaiacol glycosides & $9.8 \pm 0.9^{c}$ & $10.3 \pm 1.8^{c}$ & $340 \pm 22.7^{a}$ & $258 \pm 15^{b}$ & $<0.001$ \\
\hline 4-methylguaiacol glycosides & $2.9 \pm 0.4^{\mathrm{c}}$ & $2.3 \pm 0.4^{c}$ & $79 \pm 2.4^{\mathrm{a}}$ & $62 \pm 1.2^{b}$ & $<0.001$ \\
\hline phenol glycosides & $3.0 \pm 0.2^{c}$ & $3.4 \pm 0.7^{\mathrm{c}}$ & $111 \pm 2.4^{\mathrm{a}}$ & $98 \pm 2.1^{b}$ & $<0.001$ \\
\hline cresol glycosides & $4.3 \pm 0.1^{\mathrm{c}}$ & $4.3 \pm 0.9^{\mathrm{c}}$ & $117 \pm 4.9^{\mathrm{a}}$ & $100 \pm 3.3^{b}$ & $<0.001$ \\
\hline syringol glycosides & $12.2 \pm 0.7^{\mathrm{c}}$ & $13.4 \pm 0.6^{\mathrm{c}}$ & $614 \pm 5.1^{\mathrm{a}}$ & $473 \pm 15^{b}$ & $<0.001$ \\
\hline 4-methylsyringol glycosides & $\operatorname{tr}$ & $\operatorname{tr}$ & $38 \pm 1.2^{\mathrm{a}}$ & $26 \pm 0.6^{b}$ & $<0.001$ \\
\hline
\end{tabular}

Data are means from three replicates $(n=3) \pm$ standard deviation; $\mathrm{nd}=$ not detected $(<0.5 \mu \mathrm{g} / \mathrm{L})$; $\operatorname{tr}=\operatorname{trace}(0.5-1 \mu \mathrm{g} / \mathrm{L})$. Different letters (within rows) indicate statistical significance ( $p=0.05$, one-way ANOVA); ns $=$ not significant. Volatile phenol glycosides measured as syringol glucose-glucoside equivalents.

Ozonation of smoke-exposed grapes resulted in wines with significantly lower concentrations of guaiacol, 4-methylguaiacol, and syringol (i.e., 16-23\% decreases, Table 1) and most of the volatile phenol glycosides that were measured (i.e., $~ 12-31 \%$ decreases, Table S1), the exceptions being guaiacol glucose-glucoside and phenol glucoside, for which the concentrations did not significantly change. These results further demonstrate that post-harvest ozonation of grapes can mitigate the compositional effects of grapevine smoke exposure. However, where grapes are heavily tainted by smoke (as in the current study), a substantial proportion of smoke taint marker compounds remain in the resulting wine and might therefore still impart perceivable smoke characters.

Some small but statistically significant differences in basic chemistry measurements were also observed amongst the wines (Table 2). There were no differences in $\mathrm{pH}$, but the control wine made from grapes without $\mathrm{O}_{3}$ treatment had a significantly higher TA than other wines. This wine also had a significantly higher alcohol content; however, differences in alcohol content were not considered to be a consequence of either ozonation or smoke exposure. Grapevine exposure to smoke can affect sugar accumulation in grapes, but has only been observed where vines were repeatedly exposed to smoke during a single growing season [11]. The differences in TA and alcohol were instead attributed to variation in fruit maturity arising from phenological differences amongst vines, as reported in an earlier study [13] that was based in the same vineyard. Previous research has demonstrated that ozonation of grapes can affect the anthocyanin concentrations of juice [49] and wine [40]. In the current study, the color density of the control wine was significantly higher and its color hue was significantly lower than those observed for other wines (Table 2). The potential for differences in wine color to influence sensory analysis was therefore addressed by presenting wines to the DA panel monadically (i.e., one at a time).

Table 2. Basic chemistry of Cabernet Sauvignon wines made with control or smoke-exposed grapes, with or without post-harvest ozone treatment (1 ppm for $24 \mathrm{~h}$ ).

\begin{tabular}{|c|c|c|c|c|c|}
\hline & Control & Control $+\mathrm{O}_{3}$ & Smoke & Smoke $+\mathrm{O}_{3}$ & $p$ \\
\hline $\mathrm{pH}$ & $3.65 \pm 0.09$ & $3.71 \pm 0.01$ & $3.63 \pm 0.04$ & $3.62 \pm 0.05$ & ns \\
\hline $\mathrm{TA}(\mathrm{g} / \mathrm{L})$ & $7.3 \pm 0.2^{\mathrm{a}}$ & $6.9 \pm 0.06^{b}$ & $6.9 \pm 0.17^{b}$ & $6.9 \pm 0.16^{b}$ & 0.011 \\
\hline alcohol (\% abv) & $11.9 \pm 0.05^{\mathrm{a}}$ & $11.3 \pm 0.07^{b}$ & $10.8 \pm 0.05^{b}$ & $10.5 \pm 0.04^{b}$ & $<0.001$ \\
\hline wine color density (au) & $4.9 \pm 0.36^{\mathrm{a}}$ & $4.2 \pm 0.18^{\mathrm{b}}$ & $4.1 \pm 0.09^{b}$ & $4.0 \pm 0.06^{b}$ & 0.002 \\
\hline wine color hue & $0.79 \pm 0.01^{b}$ & $0.85 \pm 0.01^{\mathrm{a}}$ & $0.87 \pm 0.01^{\mathrm{a}}$ & $0.85 \pm 0.01^{\mathrm{a}}$ & $<0.001$ \\
\hline
\end{tabular}

Data are means from three replicates $(n=3) \pm$ standard deviation. Different letters (within rows) indicate statistical significance $(p=0.05$, one-way ANOVA). 


\subsection{Influence of Post-Harvest Ozonation on Wine Sensory Profiles}

The sensory profiles of wines made from control or smoke-exposed grapes and with or without ozonation ( $1 \mathrm{ppm}$ for $24 \mathrm{~h}$ ) are shown in Figure 1. The DA panel did not perceive any significant differences between the two control wines (i.e., due to ozonation). These wines both exhibited fruit aromas and flavors, and there were no apparent smoky or ashy characters (ratings for smoke-related attributes were low, i.e., $\leq 1.8$, Table S2); a drying aftertaste was perceived (Figure 1, Table S2), but was rated similarly in all wines and was therefore not considered to reflect either smoke exposure or $\mathrm{O}_{3}$ treatment. In contrast, the wines made with smoke-exposed grapes exhibited diminished fruit aromas and flavors, as well as perceivable smoke, cold ash, burnt rubber, and medicinal aromas, smoky and medicinal flavors, and an ashy aftertaste (Figure 1, Table S2), i.e., sensory attributes indicative of smoke taint $[4,8,10,13]$.

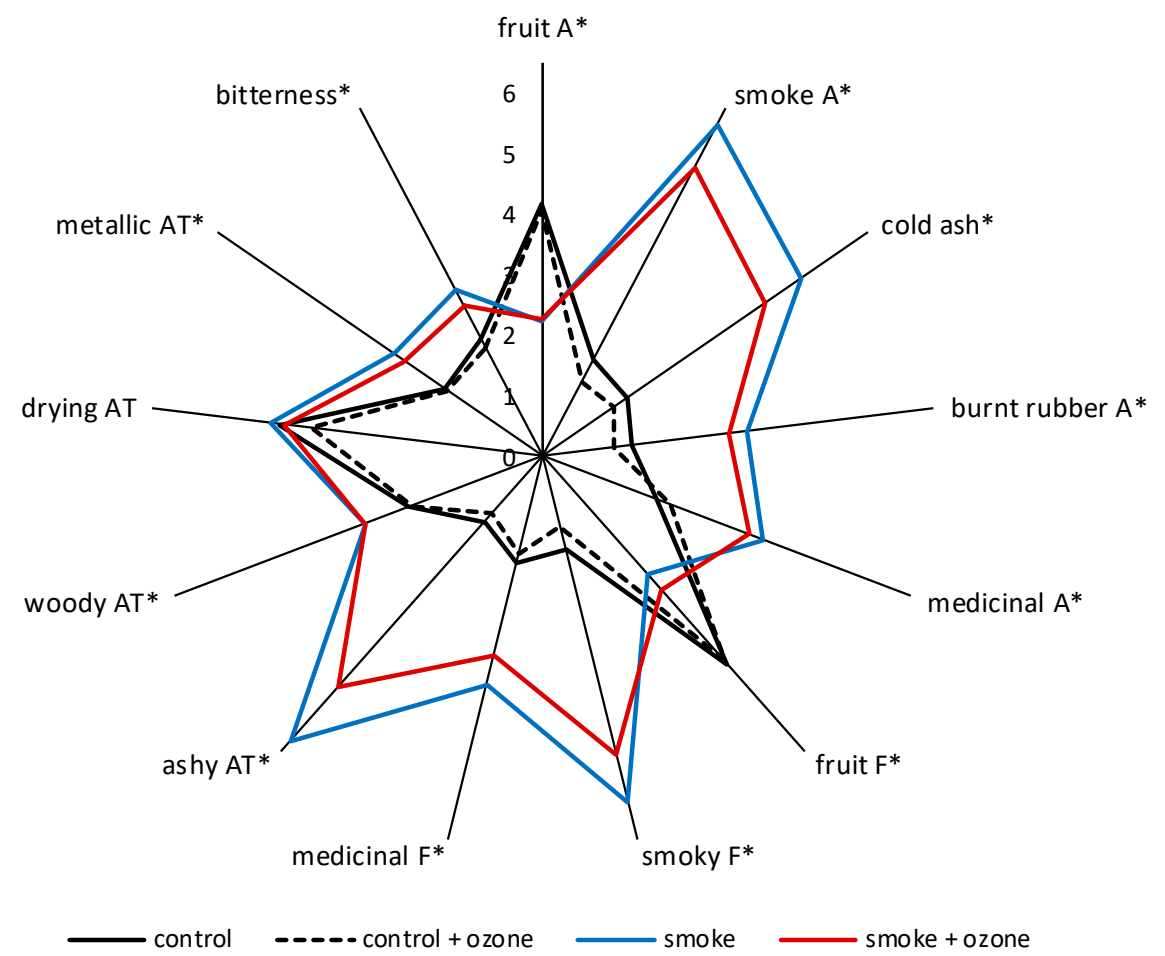

Figure 1. Sensory profiles of Cabernet Sauvignon wines made with control or smoke-exposed grapes, with or without post-harvest ozone treatment $(1 \mathrm{ppm}$ for $24 \mathrm{~h}) . \mathrm{A}=$ aroma; $\mathrm{F}=$ flavor; $\mathrm{AT}=$ aftertaste. Data are mean ratings from three wine replicates, each evaluated by 15 judges; ${ }^{*}$ indicates statistical significance ( $p=0.05$, two-way ANOVA).

The mean intensity ratings given to smoke-related sensory attributes-smoke and cold ash aromas, smoky and medicinal flavors, and ashy aftertaste, in particular-were generally lower for wines made from smoke-exposed grapes that were treated with $\mathrm{O}_{3}$ post-harvest than for wines made from smoke-exposed grapes that were not ozonated (Figure 1, Table S2). However, these ratings were not statistically significant. Whereas post-harvest ozonation of moderately smoke-affected Merlot grapes (at $1 \mathrm{ppm}$ for $24 \mathrm{~h}$ ) significantly improved wine sensory properties-i.e., fruit characters were enhanced and smoke attributes diminished [31] - the Cabernet Sauvignon grapes treated in the current study were more heavily tainted (due to exposure to dense smoke achieved by deliberately burning more fuel). As such, despite achieving a significant reduction in free and glycosylated volatile phenol concentrations using the same $\mathrm{O}_{3}$ treatment (i.e., $1 \mathrm{ppm}$ for $24 \mathrm{~h}$; Table 1), the resulting wine still exhibited a perceptible taint (Figure 1). This suggests that the efficacy of $\mathrm{O}_{3}$ treatment depends on the degree to which grapes are tainted by smoke and that ozonation might only be suitable for amelioration of grapes with low to moderate 
levels of smoke taint. Where smoke exposure occurs immediately prior to harvest, ozone treatment might still offer an effective approach to the remediation of smoke taint, given that volatile phenols appear to be more susceptible to the effects of ozonation than their glycosides [31].

\section{Conclusions}

Smoke taint will remain a challenge for grapegrowers and wine producers while bushfires continue to occur in or near wine regions during the annual growing season. As such, strategies are needed to mitigate or ameliorate the impacts of grapevine smoke exposure. Post-harvest ozonation can be employed to remediate smoke-exposed grapes, but findings from the current study suggest that the efficacy of $\mathrm{O}_{3}$ treatment might be limited according to how heavily grapes are tainted by smoke. Ozonation might therefore be effective for the remediation of grapes with low to moderate levels of taint, but in the case of more heavily tainted grapes, the resulting wine might still exhibit a perceivable taint and require further amelioration using methods that remove smoke taint marker compounds from wine (e.g., nanofiltration and/or adsorbents, such as activated carbon).

Supplementary Materials: The following are available online at https:/ /www.mdpi.com/article/10 $.3390 /$ beverages7030044/s1, Table S1: Concentrations $(\mu \mathrm{g} / \mathrm{L})$ of volatile phenol glycosides in wines made with control or smoke-exposed grapes, with or without post-harvest ozone treatment (1 ppm for $24 \mathrm{~h}$ ), Table S2: Mean intensity ratings for sensory attributes of wines made with control or smoke-exposed grapes, with or without post-harvest ozone treatment (1 ppm for $24 \mathrm{~h}$ ).

Author Contributions: All authors were involved in the conceptualization; methodology, M.M., C.S., R.R., W.J., J.C. and C.C.; resources, C.C., F.M. and K.W.; data curation, M.M., C.S., R.R. and K.W.; writing — original draft preparation, M.M. and K.W.; writing—review and editing, all authors; supervision, F.M., K.W. and P.T. All authors have read and agreed to the published version of the manuscript.

Funding: M.M. was funded as part of a PhD program in Agrobiosciences at the Life Sciences Institute in the Sant'Anna School of Advanced Study (Pisa, Italy). C.S. was funded by the Australian Research Council Training Centre for Innovative Wine Production (www.arcwinecentre.org.au), which is funded as part of the ARC's Industrial Transformation Research Program (Project No. IC170100008), with support from Wine Australian and industry partners. R.R. was supported by Australian grapegrowers and winemakers through their investment body, Wine Australia, with matching funds from the Australian Government. J.C and W.J. were supported by the AWRI and through funding from the Australian Government Department of Agriculture, Water, and the Environment as part of its Rural R\&D for Profit program and Wine Australia.

Institutional Review Board Statement: This study was approved by the Human Research Ethics Committee of the University of Adelaide (H-2019-095).

Informed Consent Statement: DA panelists gave informed consent before participating in this study.

Data Availability Statement: The data presented in this study are available on request from the corresponding author (pending privacy and ethical considerations).

Acknowledgments: The authors gratefully acknowledge the AWRIs Commercial Services Laboratory for the GC-MS analysis of wine, as well as the University of Adelaide and AWRI staff and students who participated in the sensory analysis. Special thanks is also given to Andrea Bellincontro (Tuscia University, Viterbo, Italy), who contributed to the development of the ozone application methods.

Conflicts of Interest: The authors declare no conflict of interest. The funding bodies had no role in the design of the study, in the collection, analyses, or interpretation of data, in the writing of the manuscript, or in the decision to publish the results. 


\section{References}

1. Moritz, M.A.; Parisien, M.-A.; Batllori, E.; Krawchuk, M.A.; Van Dorn, J.; Ganz, D.J.; Hayhoe, K. Climate change and disruptions to global fire activity. Ecosphere 2012, 3, 1-22. [CrossRef]

2. Krstic, M.P.; Johnson, D.L.; Herderich, M.J. Review of smoke taint in wine: Smoke-derived volatile phenols and their glycosidic metabolites in grapes and vines as biomarkers for smoke exposure and their role in the sensory perception of smoke taint. Aust. J. Grape Wine Res. 2015, 21, 537-553. [CrossRef]

3. Mirabelli-Montan, Y.A.; Marangon, M.; Graça, A.; Marangon, C.M.; Wilkinson, K.L. Techniques for mitigating the effects of smoke taint while maintaining quality in wine production. Molecules 2021, 26, 1672. [CrossRef]

4. Kennison, K.R.; Gibberd, M.R.; Pollnitz, A.P.; Wilkinson, K.L. Smoke-derived taint in wine: The release of smoke-derived volatile phenols during fermentation of Merlot juice following grapevine exposure to smoke. J. Agric. Food Chem. 2008, 56, 7379-7383. [CrossRef]

5. Sheppard, S.I.; Dhesi, M.K.; Eggers, N.J. Effect of pre- and post-veraison smoke exposure on guaiacol and 4-methylguaiacol concentration in mature grapes. Am. J. Enol. Vitic. 2009, 60, 98-103.

6. Hayasaka, Y.; Baldock, G.A.; Parker, M.; Pardon, K.H.; Black, C.A.; Herderich, M.J.; Jeffery, D.W. Glycosylation of smoke derived volatile phenols in grapes as a consequence of grapevine exposure to bushfire smoke. J. Agric. Food Chem. 2010, 58, 10989-10998. [CrossRef] [PubMed]

7. Wilkinson, K.L.; Ristic, R.; Pinchbeck, K.A.; Fudge, A.L.; Singh, D.P.; Pitt, K.M.; Downey, M.O.; Baldock, G.A.; Hayasaka, Y.; Parker, M.; et al. Comparison of methods for the analysis of smoke related phenols and their conjugates in grapes and wine. Aust. J. Grape Wine Res. 2011, 17, S22-S28. [CrossRef]

8. Ristic, R.; Fudge, A.L.; Pinchbeck, K.A.; De Bei, R.; Fuentes, S.; Hayasaka, Y.; Tyerman, S.D.; Wilkinson, K.L. Impact of grapevine exposure to smoke on vine physiology and the composition and sensory properties of wine. Theor. Exp. Plant Phys. 2016, 28, 67-83. [CrossRef]

9. Noestheden, M.; Dennis, E.G.; Zandberg, W. Quantitating volatile phenols in Cabernet Franc berries and wine after on-vine exposure to smoke from a simulated forest fire. J. Agric. Food Chem. 2018, 66, 695-703. [CrossRef]

10. Parker, M.; Osidacz, P.; Baldock, G.A.; Hayasaka, Y.; Black, C.A.; Pardon, K.H.; Jeffery, D.W.; Geue, J.P.; Herderich, M.J.; Francis, I.L. Contribution of several volatile phenols and their glycoconjugates to smoke-related sensory properties of red wine. J. Agric. Food Chem. 2012, 60, 2629-2637. [CrossRef]

11. Kennison, K.R.; Wilkinson, K.L.; Pollnitz, A.P.; Williams, H.G.; Gibberd, M.R. Effect of timing and duration of grapevine exposure to smoke on the composition and sensory properties of wine. Aust. J. Grape Wine Res. 2009, 15, 228-237. [CrossRef]

12. Kennison, K.R.; Wilkinson, K.L.; Pollnitz, A.P.; Williams, H.G.; Gibberd, M.R. Effect of smoke application to field-grown Merlot grapevines at key phenological growth stages on wine sensory and chemical properties. Aust. J. Grape Wine Res. 2011, 17, S5-S12. [CrossRef]

13. Szeto, C.; Ristic, R.; Capone, D.; Puglisi, C.; Pagay, V.; Culbert, J.; Jiang, W.; Herderich, M.; Tuke, J.; Wilkinson, K. Uptake and glycosylation of smoke-derived volatile phenols by Cabernet Sauvignon grapes and their subsequent fate during winemaking. Molecules 2020, 25, 3720. [CrossRef] [PubMed]

14. Wittkowski, R.; Ruther, J.; Drinda, H.; Rafiei-Taghanaki, F. Formation of smoke flavor compounds by thermal lignin degradation. In Flavor Precursors: Thermal and Enzymatic Conversions; Teranishi, R., Takeoka, G.R., Güntert, M., Eds.; American Chemical Society: Washington, DC, USA, 1992; pp. 232-243. [CrossRef]

15. Kennison, K.R.; Wilkinson, K.L.; Williams, H.G.; Smith, H.G.; Gibberd, M.R. Smoke-derived taint in wine: Effect of post-harvest smoke exposure of grapes on the chemical composition and sensory characteristics of wine. J. Agric. Food Chem. 2007, 55, 10897-10901. [CrossRef] [PubMed]

16. Hayasaka, Y.; Dungey, K.A.; Baldock, G.A.; Kennison, K.R.; Wilkinson, K.L. Identification of a $\beta$-D-glucopyranoside precursor to guaiacol in grape juice following grapevine exposure to smoke. Anal. Chim. Acta 2010, 660, 143-148. [CrossRef]

17. Hayasaka, Y.; Baldock, G.A.; Pardon, K.H.; Jeffery, D.W.; Herderich, M.J. Investigation into the formation of guaiacol conjugates in berries and leaves of grapevine Vitis vinifera L. cv. Cabernet Sauvignon using stable isotope tracers combined with HPLC-MS and MS/MS analysis. J. Agric. Food Chem. 2010, 58, 2076-2081. [CrossRef] [PubMed]

18. Noestheden, M.; Dennis, E.G.; Romero-Montalvo, E.; DiLabio, G.A.; Zandberg, W.F. Detailed characterization of glycosylated sensory-active volatile phenols in smoke-exposed grapes and wine. Food Chem. 2018, 259, 147-156. [CrossRef]

19. van der Hulst, L.; Munguia, P.; Culbert, J.A.; Ford, C.M.; Burton, R.A.; Wilkinson, K.L. Accumulation of volatile phenol glycoconjugates in grapes following grapevine exposure to smoke and potential mitigation of smoke taint by foliar application of kaolin. Planta 2019, 249, 941-952. [CrossRef]

20. Caffrey, A.; Lerno, L.; Rumbaugh, A.; Girardello, R.; Zweigenbaum, J.; Oberholster, A.; Ebeler, S.E. Changes in smoke-taint volatile-phenol glycosides in wildfire smoke-exposed Cabernet Sauvignon grapes throughout winemaking. Am. J. Enol. Vitic. 2019, 70, 373-381. [CrossRef]

21. Härtl, K.; Huang, F.-C.; Giri, A.P.; Franz-Oberdorf, K.; Frotscher, J.; Shao, Y.; Hoffmann, T.; Schwab, W. Glucosylation of smokederived volatiles in grapevine (Vitis vinifera) is catalyzed by a promiscuous resveratrol/guaiacol glucosyltransferase. J. Agric. Food Chem. 2017, 65, 5681-5689. [CrossRef] 
22. Mayr, C.M.; Parker, M.; Baldock, G.A.; Black, C.A.; Pardon, K.H.; Williamson, P.O.; Herderich, M.J.; Francis, I.L. Determination of the importance of in-mouth release of volatile phenol glycoconjugates to the flavor of smoke-tainted wines. J. Agric. Food Chem. 2014, 62, 2327-2336. [CrossRef]

23. Dungey, K.A.; Hayasaka, Y.; Wilkinson, K.L. Quantitative analysis of glycoconjugate precursors of guaiacol in smoke-affected grapes using liquid chromatography-tandem mass spectrometry based stable isotope dilution analysis. Food Chem. 2011, 126, 801-806. [CrossRef]

24. Hayasaka, Y.; Parker, M.; Baldock, G.A.; Pardon, K.H.; Black, C.A.; Jeffery, D.W.; Herderich, M.J. Assessing the impact of smoke exposure in grapes: Development and validation of an HPLC-MS/MS method for the quantitative analysis of smoke-derived phenolic glycosides in grapes and wine. J. Agric. Food Chem. 2013, 61, 25-33. [CrossRef] [PubMed]

25. Ristic, R.; Pinchbeck, K.A.; Fudge, A.L.; Hayasaka, Y.; Wilkinson, K.L. Effect of leaf removal and grapevine smoke exposure on colour, chemical composition and sensory properties of Chardonnay wines. Aust. J. Grape Wine Res. 2013, 19, 230-237. [CrossRef]

26. Favell, J.W.; Noestheden, M.; Lyons, S.M.; Zandberg, W.F. Development and evaluation of a vineyard-based strategy to mitigate smoke-taint in wine grapes. J. Agric. Food Chem. 2019, 67, 14137-14142. [CrossRef] [PubMed]

27. Ristic, R.; Osidacz, P.; Pinchbeck, K.; Hayasaka, Y.; Fudge, A.; Wilkinson, K. The effect of winemaking techniques on the intensity of smoke taint in wine. Aust. J. Grape Wine Res. 2011, 17, S29-S40. [CrossRef]

28. Fudge, A.L.; Schiettecatte, M.; Ristic, R.; Hayasaka, Y.; Wilkinson, K.L. Amelioration of smoke taint in wine by treatment with commercial fining agents. Aust. J. Grape Wine Res. 2012, 18, 302-307. [CrossRef]

29. Fudge, A.L.; Ristic, R.; Wollan, D.; Wilkinson, K.L. Amelioration of smoke taint in wine by reverse osmosis and solid phase adsorption. Aust. J. Grape Wine Res. 2011, 17, S41-S48. [CrossRef]

30. Antolini, A.; Forniti, R.; Modesti, M.; Bellincontro, A.; Catelli, C.; Mencarelli, F. First application of ozone postharvest fumigation to remove smoke taint from grapes. Ozone Sci. Eng. 2021, 43, 254-262. [CrossRef]

31. Modesti, M.; Szeto, C.; Ristic, R.; Jiang, W.; Culbert, J.; Bindon, K.; Catelli, C.; Mencarelli, F.; Tonutti, P.; Wilkinson, K. Potential mitigation of smoke taint in wines by post-harvest ozone treatment of grapes. Molecules 2021, 26, 1798. [CrossRef]

32. Miller, G.; Schlauch, K.; Tam, R.; Cortes, D.; Torres, M.A.; Shulaev, V.; Mittler, R. The plant NADPH oxidase RBOHD mediates rapid systemic signaling in response to diverse stimuli. Sci. Signal 2009, 2, ra45. [CrossRef]

33. Artés-Hernández, F.; Aguayo, E.; Artés, F.; Tomás-Barberán, F. Enriched ozone atmosphere enhances bioactive phenolics in seedless table grapes after prolonged shelf life. J. Sci. Food Agric. 2007, 87, 824-831. [CrossRef]

34. Carbone, K.; Mencarelli, F. Influence of short-term postharvest ozone treatments in nitrogen or air atmosphere on the metabolic response of white wine grapes. Food Bioprocess Technol. 2015, 8, 1739-1749. [CrossRef]

35. Karaca, H. The effects of ozone-enriched storage atmosphere on pesticide residues and physicochemical properties of table grapes. Ozone Sci. Eng. 2019, 5, 404-414. [CrossRef]

36. Pandiselvam, R.; Kaavya, R.; Yasendra, J.; Veenuttranon, K.; Lueprasitsakul, P.; Divya, V.; Kothakota, A.; Ramesh, S.V. Ozone as a novel emerging technology for the dissipation of pesticide residues in foods-a review. Trends Food Sci. Technol. 2020, 97, 38-54. [CrossRef]

37. Smilanick, J.L.; Margosan, D.M.; Gabler, F.M. Impact of ozonated water on the quality and shelf-life of fresh citrus fruit, stone fruit, and table grapes. Ozone Sci. Eng. 2002, 24, 343-356. [CrossRef]

38. Botondi, R.; De Sanctis, F.; Moscatelli, N.; Vettraino, A.M.; Catelli, C.; Mencarelli, F. Ozone fumigation for safety and quality of wine grapes in postharvest dehydration. Food Chem. 2015, 188, 641-647. [CrossRef]

39. Cravero, F.; Englezos, V.; Rantsiou, K.; Torchio, F.; Giacosa, S.; Río Segade, S.; Gerbi, V.; Rolle, L.; Cocolin, L. Ozone treatments of post harvested wine grapes: Impact on fermentative yeasts and wine chemical properties. Food Res. Int. 2016, 87, 134-141. [CrossRef]

40. Bellincontro, A.; Catelli, C.; Cotarella, R.; Mencarelli, F. Postharvest ozone fumigation of Petit Verdot grapes to prevent the use of sulfites and to increase anthocyanin in wine. Aust. J. Grape Wine Res. 2017, 23, 200-206. [CrossRef]

41. Río Segade, S.; Vilanova, M.; Giacosa, S.; Perrone, I.; Chitarra, W.; Pollon, M.; Torchio, F.; Boccacci, P.; Gambino, G.; Gerbi, V.; et al. Ozone improves the aromatic fingerprint of white grapes. Sci. Rep. 2017, 7, 16301. [CrossRef]

42. Modesti, M.; Petriccione, M.; Forniti, R.; Zampella, L.; Mastrobuoi, F.; Scortichini, M.; Mencarelli, F. Methyl jasmonate and ozone affect the antioxidant system and the quality of wine grape during postharvest partial dehydration. Food Res. Int. 2018, 112, 369-377. [CrossRef] [PubMed]

43. Mercurio, M.D.; Dambergs, R.G.; Herderich, M.J.; Smith, P.A. High throughput analysis of red wine and grape phenolicsAdaptation and validation of methyl cellulose precipitable tannin assay and modified Somers color assay to a rapid 96 well plate format. J. Agric. Food Chem. 2007, 55, 4651-4657. [CrossRef]

44. Pollnitz, A.P.; Pardon, K.H.; Sykes, M.; Sefton, M.A. The effects of sample preparation and gas chromatograph injection techniques on the accuracy of measuring guaiacol, 4-methylguaiacol and other volatile oak compounds in oak extracts by stable isotope dilution analyses. J. Agric. Food Chem. 2004, 52, 3244-3252. [CrossRef]

45. Lawless, H.T.; Heymann, H. Descriptive analysis. In Sensory Evaluation of Food; Springer: New York, NY, USA, 2010 ; pp. $227-257$. [CrossRef]

46. Ristic, R.; Boss, P.K.; Wilkinson, K.L. Influence of fruit maturity at harvest on the intensity of smoke taint in wine. Molecules 2015, 20, 8913-8927. [CrossRef] 
47. Ristic, R.; van der Hulst, L.; Capone, D.L.; Wilkinson, K.L. Impact of bottle aging on smoke-tainted wines from different grape cultivars. J. Agric. Food Chem. 2017, 65, 4146-4152. [CrossRef]

48. Wilkinson, K.L.; Ristic, R. Comparing the chemical and sensory consequences of grapevine smoke exposure in grapes and wine from different cultivars and different wine regions in Australia. In Proceedings of the XIIIth International Terroir Congress, Adelaide, Australia, 17-18 November 2020; International Viticulture and Oenology Society: Villenave d'Ornon, France, 2021.

49. Tiwari, B.K.; O'Donnell, C.P.; Patras, A.; Brunton, N.; Cullen, P.J. Anthocyanins and color degradation in ozonated grape juice. Food Chem. Toxicol. 2009, 47, 2824-2829. [CrossRef] 